\title{
Scribes as Editors: Tracking Changes in the Linear B Documents
}

\author{
ANNA P. JUDSON
}

A wide variety of edits can be identified in the Linear B administrative documents from Mycenaean Greece. The writers of these documents (the Mycenaean scribes) can be seen to have made changes to their texts by erasing, rewriting, or adding signs, words, or whole entries. The edits include not only correcting errors and updating information (as might be expected for these administrative documents) but also a wide variety of changes that affect the texts' presentation rather than their content, such as alterations to their layout, textual structure, and orthography, and even the forms of individual signs. By analyzing these edits and the motivations behind them, this article sheds light on the priorities of the Mycenaean scribes in creating and using their administrative documents and the choices they made in the process of doing so. The results demonstrate that despite these records' short-term nature (tablets were kept for no longer than a year) they were not merely rough or preliminary texts over which relatively little care was taken but were active documents designed for ongoing use and consultation within the Mycenaean palatial administrations' yearly administrative cycles. ${ }^{1}$

\section{INTRODUCTION}

This article investigates the ways in which the writers of the Linear B tablets made changes to their documents, what these edits reveal about the scribes' choices and priorities in creating and using these administrative records, and the impact these findings have on our understanding of the role played by the tablets in the Mycenaean administrative systems. ${ }^{2}$ These originally

American Journal of Archaeology

Volume 124, Number 4

October 2020

Pages 523-49

DOI: $10.3764 /$ aja.124.4.0523

www.ajaonline.org

\footnotetext{
${ }^{1}$ This paper was written during a Research Fellowship in Classics at Gonville and Caius College, Cambridge. Previous versions were presented at the Cambridge Aegean Archaeology Group Conference, McDonald Institute for Archaeological Research, Cambridge (June 2018); the Philological Society's Early Career Researcher Forum, Wolfson College, Oxford (March 2019); and at the joint 15th Congress of the Fédération internationale des associations d'études classiques and U.K. Classical Association annual conference, University College London (July 2019). I am grateful to the participants of the Cambridge Classics Postdoc Work-in-Progress Seminar for their helpful comments on a draft, and to John Bennet, AJA Editor-in-Chief Jane Carter, and Dimitri Nakassis for their detailed and constructive feedback. I also thank Dimitri Nakassis for generously supplying the photographs of the Pylos tablets illustrated in this paper, and Sharon Stocker and Carol Hershenson of the Department of Classics, University of Cincinnati, for their kind permission to use these photographs. The Linear B font used in this paper is Alphabetum, created by Juan-José Marcos (http://guindo.pntic.mec.es/jmag0042/alphaeng.html). Translations are my own.

${ }^{2}$ The Linear B tablets from the sites discussed here are located in the following museums: Knossos: Archaeological Museum of Heraklion and Ashmolean Museum, Oxford (excavated between 1900 and 1905); Mycenae: National Archaeological Museum, Athens, and Archaeological Museum of Nafplio (excavated in 1954 and 1958); Pylos: National Archaeological Museum, Athens (excavated between 1939 and 1963); Thebes: Archaeological Museum of Thebes (excavated in 1982 and 1993-1995); Tiryns: Archaeological Museum of Nafplio (excavated in 1978). For full details, see the relevant corpora (infra n. 4).
} 